\title{
In Silico Virulence and Resistance Profile Analysis of Staphylococcus species
}

\author{
Nusrat Nahar1, Ridwan Bin Rashid ${ }^{1}$, A. N. M. Hamidul Kabir ${ }^{2}$ \\ and Mohammad Sharifur Rahman ${ }^{3}$
}

\author{
${ }^{1}$ Computational Chemistry and Bioinformatics Laboratory, Department of Pharmacy, State University of \\ Bangladesh, Dhaka-1205, Bangladesh \\ ${ }^{2}$ Department of Applied Chemistry and Chemical Engineering, University of Dhaka, Dhaka-1000, Bangladesh \\ ${ }^{3}$ Department of Pharmaceutical Chemistry, Faculty of Pharmacy, University of Dhaka, Dhaka-1000, Bangladesh
}

Received: December 18, 2016; Accepted: January 09, 2017; Published (Web): March 19, 2017

\begin{abstract}
In silico studies of the genes of Staphylococcus spp. might establish some correlations with multiple pathological factors. Sixty isolates of Staphylococcus spp. have been studied here targeting virulence and antibiotic resistance genes through in silico tools. Here, in silico PCR (polymerase chain reaction) amplification detected both virulence and antibiotic resistance genes. Study revealed that most of the isolates harboured either cap5 (40\%) or cap8 (31.67\%) locus gene. Staphylococcal enterotoxin was detected in $63.33 \%$ of the isolates. The sea gene, responsible for food poisoning, was detected in $26.67 \%$ of the isolates. The tst positive isolates $(5 \%)$, responsible for toxic shock syndrome, were present in only genotype 8 . No exfoliative toxin was detected. The icaA gene, responsible for intracellular adherence, appeared in $80 \%$ of the isolates. Alpha hemolysin gene, hla, was detected in $63.33 \%$ of the isolates. Sixty-five percent of the isolates harboured the mecA genes. Both $\beta$-lactamase (blaZ) and erythromycin resistance, ermA genes were available in $38.33 \%$ of the isolates. In silico pulsed field gel electrophoresis (PFGE) digestion was able to divide isolates into 23 genotypes. Genotype 8 and 11 harboured tetracycline resistance genes, tet $M$ and tetK. The tetM gene (18.33\%) was more prevalent than tetK gene (11.67\%). Genotype 1 and 11 were considered more virulent than others. Genotype 11 also carried six antibiotic resistance genes but did not carry the genes $m s r A$, $m s r B$, ermB and ermC. The data generated here might aid in the prediction of the virulence and resistance profile based on genotyping as well as contribute in vaccine development.
\end{abstract}

Key words: Staphylococcus, Virulence genes, Antibiotic resistance genes, Pulse field gel electrophoresis, Genotype.

\section{Introduction}

Staphylococcus is a gram-positive commensal organism found in the skin, skin glands, hair, intestinal tract, genitourinary tract, upper respiratory tract and mucous membranes. The pathogenicity of bacteria depends on some virulence factors such as surface proteins, extracellular material, cellular proteins, toxins and protease. Capsular polysaccharide protects bacteria from phagocytic uptake and out of 11 capsular polysaccharides, only type 5 and 8 are predominant among clinical isolates (Hochkeppel et al., 1987). Enterotoxins are associated with the food poisoning outbreak (Hennekinne et al., 2012; Argudin et al., 2012). Fueyo et al. (2005) reported that toxic shock syndrome is caused by the exotoxin gene, tst. Kim et al. (2006) published that exfoliative toxins (ETs) are associated with skin infection. Epithelial layer disruption caused by hemolysin gene was reported earlier by Vandenesch et al. (2012). Multidrug resistance is a serious consequence of treatment and prevention of Staphylococcus infection. Duran et al. (2012) demonstrated that aminoglycoside nucleotidyltransferase (APHs) inactivates drug and confers resistance to aminoglycoside antibiotics. Clinical isolates carry ermA or ermC but the ermB gene is rather infrequent (Schmitz et al., 2000). Schmitz et al. (2000) and Torres et al. (1996) reported that tetracycline resistance in Staphylococcus spp. is acquired by 
ribosomal modification of widely disseminated tet $M$ or tet $K$ gene and tet $K$ is found most often in Staphylococcus aureus (Trzcinski et al., 2000; Schmitz et al., 2001). In silico analysis helps to extract useful information from vast amount of data. Recently, numerous in silico gene analysis have been conducted by using numerous tools. In this regard, a throughout knowledge of molecular evaluation might assist to control bacterial dissemination (Bikandi et al., 2004; San Millan et al., 2013; Biswas et al., 2008; Zankari et. al., 2012). Comparative genomics helps to improve knowledge on pathogenesis and drug resistance of microbial species (Feng et al., 2008).

The aim of the present study was to thorough in silico investigation of 60 Staphylococcus spp. and predict the virulence and resistance profile of this genus.

\section{Materials and Methods}

Strains used in the study: Isolates used in this study are summarized in Table 1.

Table 1. Name of the isolates.

\begin{tabular}{|c|c|}
\hline $\begin{array}{c}\text { Serial } \\
\text { Number }\end{array}$ & Isolate Name \\
\hline 1 & NC_017340 Staphylococcus aureus 04-02981 \\
\hline 2 & NC_018608 Staphylococcus aureus 08BA02176 \\
\hline 3 & NC-021670 Staphylococcus aureus Bmb9393 \\
\hline 4 & NC_021554 Staphylococcus aureus CA-347 \\
\hline 5 & NC_021059 Staphylococcus aureus M1 \\
\hline 6 & NC_007622 Staphylococcus aureus RF122 \\
\hline 7 & NC_002758 Staphylococcus aureus strain Mu50 \\
\hline 8 & NC_017451 Staphylococcus aureus subsp. aureus 11819-97 \\
\hline 9 & NC_022113 Staphylococcus aureus subsp. aureus 55/2053 \\
\hline 10 & NC_022222 Staphylococcus aureus subsp. aureus 6850 \\
\hline 11 & NC_017673 Staphylococcus aureus subsp. aureus 71193 \\
\hline 12 & NC_022226 Staphylococcus aureus subsp. aureus CN1 \\
\hline 13 & NC_002951 Staphylococcus aureus subsp. aureus COL \\
\hline 14 & NC_017343 Staphylococcus aureus subsp. aureus ECT-R 2 \\
\hline 15 & NC_017337 Staphylococcus aureus subsp. aureus ED133 \\
\hline 16 & NC_013450 Staphylococcus aureus subsp. aureus ED98 \\
\hline 17 & NC_017763 Staphylococcus aureus subsp. aureus HO 50960412 \\
\hline 18 & NC_009632 Staphylococcus aureus subsp. aureus JH1 \\
\hline 19 & NC_009487 Staphylococcus aureus subsp. aureus JH9 \\
\hline 20 & NC_017338 Staphylococcus aureus subsp. aureus JKD6159 \\
\hline 21 & NC_017349 Staphylococcus aureus subsp. aureus LGA251 \\
\hline 22 & NC_016928 Staphylococcus aureus subsp. aureus M013 \\
\hline 23 & NC_002952 Staphylococcus aureus subsp. aureus MRSA252 \\
\hline 24 & NC_016941 Staphylococcus aureus subsp. aureus MSHR1132 \\
\hline 25 & NC_002953 Staphylococcus aureus subsp. aureus MSSA476 \\
\hline 26 & NC_003923 Staphylococcus aureus subsp. aureus MW2 \\
\hline 27 & NC_009782 Staphylococcus aureus subsp. aureus Mu3 \\
\hline 28 & NC_002745 Staphylococcus aureus subsp. aureus N315 \\
\hline 29 & NC_007795 Staphylococcus aureus subsp. aureus NCTC 8325 \\
\hline 30 & NC_017333 Staphylococcus aureus subsp. aureus S0385 \\
\hline 31 & NC_022443 Staphylococcus aureus subsp. aureus SA40 \\
\hline 32 & NC_022443 Staphylococcusaureus subsp. aureus SA957 \\
\hline 33 & NC_020529 Staphylococcus aureus subsp. aureus ST228 complete genome, isolate 10388 \\
\hline 34 & NC_020564 Staphylococcus aureus subsp. aureus ST228 complete genome, isolate 10497 \\
\hline
\end{tabular}


Table 1 contd.

\begin{tabular}{|c|c|}
\hline 35 & NC_020532 Staphylococcus aureus subsp. aureus ST228 complete genome, isolate 15532 \\
\hline 36 & NC_020533 Staphylococcus aureus subsp. aureus ST228 complete genome, isolate 16035 \\
\hline 37 & NC_020566 Staphylococcus aureus subsp. aureus ST228 complete genome, isolate 16125 \\
\hline 38 & NC_020536 Staphylococcus aureus subsp. aureus ST228 complete genome, isolate 18341 \\
\hline 39 & NC_020537 Staphylococcus aureus subsp. aureus ST228 complete genome, isolate 18412 \\
\hline 40 & NC_020568 Staphylococcus aureus subsp. aureus ST228 complete genome, isolate 18583 \\
\hline 41 & NC_017342 Staphylococcus aureus subsp. aureus T0131 \\
\hline 42 & NC_017343 Staphylococcus aureus subsp. aureus TCH60 \\
\hline 43 & NC_017331 Staphylococcus aureus subsp. aureus TW20 \\
\hline 44 & NC_007793 Staphylococcus aureus subsp. aureus USA300_FPR3757 \\
\hline 45 & NC_010079 Staphylococcus aureus subsp. aureus USA300_TCH1516 \\
\hline 46 & NC_016912 Staphylococcus aureus subsp. aureus VC40 \\
\hline 47 & NC_022604 Staphylococcus aureus subsp. aureus Z172 \\
\hline 48 & NC_017341 Staphylococcus aureus subsp. aureus str. JKD6008 \\
\hline 49 & NC_009641 Staphylococcus aureus subsp. aureus str. Newman \\
\hline 50 & NC_012121 Staphylococcus carnosus subsp. carnosus TM300 \\
\hline 51 & NC_004461 Staphylococcus epidermidis ATCC_12228 \\
\hline 52 & NC_002976 Staphylococcus epidermidis RP62A \\
\hline 53 & NC_007168 Staphylococcus haemolyticus JCSC1435 \\
\hline 54 & NC_013893 Staphylococcus lugdunensis HKU09-01 \\
\hline 55 & NC_0173533 Staphylococcus lugdunensis N920143 \\
\hline 56 & NC_022737 Staphylococcus pasteuri SP1 \\
\hline 57 & NC_017568 Staphylococcus pseudintermedius ED99 \\
\hline 58 & NC_014925 Staphylococcus pseudintermedius HKU10-03 \\
\hline 59 & NC_007350 Staphylococcus saprophyticus subsp. saprophyticus \\
\hline 60 & NC_020164 Staphylococcus warneri SG1 \\
\hline
\end{tabular}

PCR primers: The primers used in the study are summarized in the table below:

Table 2. Primer used for detection of virulence genes.

\begin{tabular}{|c|c|c|c|c|}
\hline Virulence factor & Gene & Primer Sequence ( $5^{\prime}$ to $\left.3^{\prime}\right)$ & $\begin{array}{l}\text { Amplicon } \\
\text { size (bp) }\end{array}$ & Reference \\
\hline $\begin{array}{l}\text { Intracellular } \\
\text { adhesin }\end{array}$ & icaA & $\begin{array}{l}\text { GATTATGTAATGTGCTTGGA } \\
\text { ACTACTGCTGCGTTAATAAT }\end{array}$ & 770 & Peacock et al., 2002 \\
\hline Putative adhesin & $s d r E$ & $\begin{array}{l}\text { AGTAAAATGTGTCAAAAGA } \\
\text { TTGACTACCAGGCTATAT }\end{array}$ & 767 & Peacock et al., 2002 \\
\hline $\begin{array}{l}\text { Bone bound } \\
\text { sialoprotein gene }\end{array}$ & $b b p$ & $\begin{array}{l}\text { AACTACATCTAGTACTCAACAACAG } \\
\text { ATGTGCTTGAATAACACCATCATCT }\end{array}$ & 574 & Park et al., 2008 \\
\hline $\begin{array}{l}\text { Staphylococcal } \\
\text { enterotoxin A }\end{array}$ & sea & $\begin{array}{l}\text { GGTTATCAATGTGCGGGTGG } \\
\text { CGGCACTTTTTTCTCTTCGG }\end{array}$ & 102 & Saadati et al., 2011 \\
\hline $\begin{array}{l}\text { Staphylococcal } \\
\text { enterotoxin B }\end{array}$ & $s e b$ & $\begin{array}{l}\text { GTATGGTGGTGTAACTGAGC } \\
\text { CCAAATAGTGACGAGTTAGG }\end{array}$ & 168 & Saadati et al., 2011 \\
\hline $\begin{array}{l}\text { Staphylococcal } \\
\text { enterotoxin C }\end{array}$ & sec & $\begin{array}{l}\text { CTCAAGAACTAGACATAAAAGCTAGG } \\
\text { TTATATCAAAATCGGATTAACATTATC }\end{array}$ & 276 & Saadati et al., 2011 \\
\hline $\begin{array}{l}\text { Staphylococcal } \\
\text { enterotoxin D }\end{array}$ & sed & $\begin{array}{l}\text { CCAATAATAGGAGAAAATAAAAG } \\
\text { ATTGGTATTTTTTTTCGTTC }\end{array}$ & 278 & Saadati et al., 2011 \\
\hline $\begin{array}{l}\text { Staphylococcal } \\
\text { enterotoxin E }\end{array}$ & see & $\begin{array}{l}\text { CAGTACCTATAGATAAAGTTAAAACAAGC } \\
\text { TAACTTACCGTGGACCCTTCAG }\end{array}$ & 178 & Saadati et al., 2011 \\
\hline $\begin{array}{l}\text { Staphylococcal } \\
\text { enterotoxin Q }\end{array}$ & seq & $\begin{array}{l}\text { AATCTCTGGGTCAATGGTAAGC } \\
\text { TTGTATTCGTTTTGTAGGTATTTTCG }\end{array}$ & 122 & Saadati et al., 2011 \\
\hline
\end{tabular}


Table 2 contd.

\begin{tabular}{|c|c|c|c|c|}
\hline $\begin{array}{l}\text { Toxic shock } \\
\text { syndrome toxin } 1\end{array}$ & tst & $\begin{array}{l}\text { ACCCCTGTTCCCTTATCATC } \\
\text { TTTTCAGTATTTGTAACGCC }\end{array}$ & 326 & Alfatemi et al., 2014 \\
\hline Exfoliative toxin A & eta & $\begin{array}{l}\text { GCAGGTGTTGATTTAGCATT } \\
\text { AGATGTCCCTATTTTTGCTG }\end{array}$ & 93 & Alfatemi et al., 2014 \\
\hline Exfoliative toxin B & etb & $\begin{array}{l}\text { ACAAGCAAAAGAATACAGCG } \\
\text { GTTTTTGGCTGCTTCTCTTG }\end{array}$ & 226 & Alfatemi et al., 2014 \\
\hline Alpha hemolysin & hla & $\begin{array}{l}\text { CTGATTACTATCCAAGAAATTCGATTG } \\
\text { CTTTCCAGCCTACTTTTTTATCAGT }\end{array}$ & 210 & Alfatemi et al., 2014 \\
\hline Beta hemolysin & $h l b$ & $\begin{array}{l}\text { GTGCACTTACTGACAATAGTGC } \\
\text { GTTGATGAGTAGCTACCTTCAGT }\end{array}$ & 310 & Jarraud et al., 2002 \\
\hline Delta hemolysin & hld & $\begin{array}{l}\text { AAGAATTTTTATCTTAATTAAGGAAGGAG } \\
\text { TGTTAGTGAATTTGTTCACTGTGTCGA }\end{array}$ & 111 & Alfatemi et al., 2014 \\
\hline Gamma hemolysin & hlg & $\begin{array}{l}\text { GCCAATCCGTTATTAGAAAATGC } \\
\text { CCATAGACGTAGCAACGGAT }\end{array}$ & 938 & Peacock et al., 2002 \\
\hline $\begin{array}{l}\text { Capsular } \\
\text { polysaccharide } 5\end{array}$ & cap5 & $\begin{array}{l}\text { ATG ACG ATG AGG ATA GCG } \\
\text { CTC GGA TAA CAC CTG TTG C }\end{array}$ & 881 & Salasia et al., 2004 \\
\hline $\begin{array}{l}\text { Capsular } \\
\text { polysaccharide } 8\end{array}$ & cap8 & $\begin{array}{l}\text { ATGACGATGAGGATAGCG } \\
\text { CACCTAACATAAGGCAAG }\end{array}$ & 1148 & Salasia et al., 2004 \\
\hline
\end{tabular}

Table 3. Primer used for detection of antibiotic resistance genes.

\begin{tabular}{|c|c|c|c|c|}
\hline $\begin{array}{l}\text { Antibiotic } \\
\text { resistance gene }\end{array}$ & Gene & Primer Sequence (5' to 3') & $\begin{array}{l}\text { Amplicon } \\
\text { size (bp) }\end{array}$ & Reference \\
\hline $\begin{array}{l}\text { Penicillin resistance } \\
\text { gene }\end{array}$ & blaz & $\begin{array}{l}\text { ACTTCAACACCTGCTGCTTTC } \\
\text { TGACCACTTTTATCAGCAACC }\end{array}$ & 173 & Martineau et al., 2000 \\
\hline $\begin{array}{l}\text { Erythromycin } \\
\text { resistance gene }\end{array}$ & ermA & $\begin{array}{l}\text { TATCTTATCGTTGAGAAGGGATT } \\
\text { CTACACTTGGCTTAGGATGAAA }\end{array}$ & 139 & Martineau et al., 2000 \\
\hline $\begin{array}{l}\text { Erythromycin } \\
\text { resistance gene }\end{array}$ & ermB & $\begin{array}{l}\text { CTATCTGATTGTTGAAGAAGGATT } \\
\text { GTTTACTCTTGGTTTAGGATGAAA }\end{array}$ & 142 & Martineau et al., 2000 \\
\hline $\begin{array}{l}\text { Erythromycin } \\
\text { resistance gene }\end{array}$ & ermC & $\begin{array}{l}\text { CTTGTTGATCACGATAATTTCC } \\
\text { ATCTTTTAGCAAACCCGTATTC }\end{array}$ & 190 & Martineau et al., 2000 \\
\hline $\begin{array}{l}\text { Oxacillin resistance } \\
\text { gene }\end{array}$ & mecA & $\begin{array}{l}\text { AACAGGTGAATTATTAGCACTTGTAAG } \\
\text { ATTGCTGTTAATATTTTTTGAGTTGAA }\end{array}$ & 174 & Martineau et al., 2000 \\
\hline $\begin{array}{l}\text { Erythromycin } \\
\text { resistance gene }\end{array}$ & $m s r A$ & $\begin{array}{l}\text { TCCAATCATTGCACAAAATC } \\
\text { AATTCCCTCTATTTGGTGGT }\end{array}$ & 163 & Martineau et al., 2000 \\
\hline $\begin{array}{l}\text { Aminoglycoside } \\
\text { resistance gene }\end{array}$ & $\begin{array}{l}\operatorname{aac}\left(6^{\prime}\right)- \\
\operatorname{aph}(2 ”)\end{array}$ & $\begin{array}{l}\text { TTGGGAAGATGAAGTTTTTAGA } \\
\text { CCTTTACTCCAATAATTTGGCT }\end{array}$ & 174 & Martineau et al., 2000 \\
\hline $\begin{array}{l}\text { Tetracycline } \\
\text { resistance gene }\end{array}$ & tetK & $\begin{array}{l}\text { GTAGCGACAATAGGTAATAGT } \\
\text { GTAGTGACAATAAACCTCCTA }\end{array}$ & 361 & Duran et al., 2012 \\
\hline $\begin{array}{l}\text { Tetracycline } \\
\text { resistance gene }\end{array}$ & tetM & $\begin{array}{l}\text { AGTGGAGCGATTACAGAA } \\
\text { CATATGTCCTGGCGTGTCTA }\end{array}$ & 159 & Duran et al., 2012 \\
\hline $\begin{array}{l}\text { Erythromycin } \\
\text { resistance gene }\end{array}$ & $m s r B$ & $\begin{array}{l}\text { TATGATATCCATAATAATTATCCAATC } \\
\text { AAGTTATATCATGAATAGATTGTCCTGTT }\end{array}$ & 595 & Momtaz et al., 2013 \\
\hline
\end{tabular}

PCR amplification: In silico PCR amplification was done in the website http://insilico.ehu.eus/PCR/ (San Millan et al., 2013; Bikandi et al., 2004).

PFGE digestion: PFGE digestion and construction of the dendrogram was done in the website http://insilico.ehu.es/digest/. The enzyme used for the digestion was SgrAl and recognition sequence was CR'CCGG_YG (San Millan et al., 2013; Bikandi et al., 2004). 


\section{Results and Discussion}

In the present study, in silico PCR amplification detected eighteen virulence genes by using gene specific primer. Capsular polysaccharides are important virulence factors in the pathogenesis of staphylococcal infection. According to O'Riordan (2004), they persist on mucosal surface and promote bacterial colonization. In this study, it was found that $40 \%(\mathrm{n}=24)$ isolates had the cap5 locus with 881 bp gene product, while $31.67 \%$ $(\mathrm{n}=19)$ isolates had the cap8 locus with 1148 bp gene product (Figure 1). So, the cap5 locus was more prevalent than that of cap8. Na'was et al. (1998) reported that type 5 serotype was predominant among MRSA (Methicillin-resistant Staphylococcus aureus) isolates. Luong et al. (2002) demonstrated that capsular polysaccharides, type 5 and 8 are clinically more prevalent and have been used as targets for vaccine development.

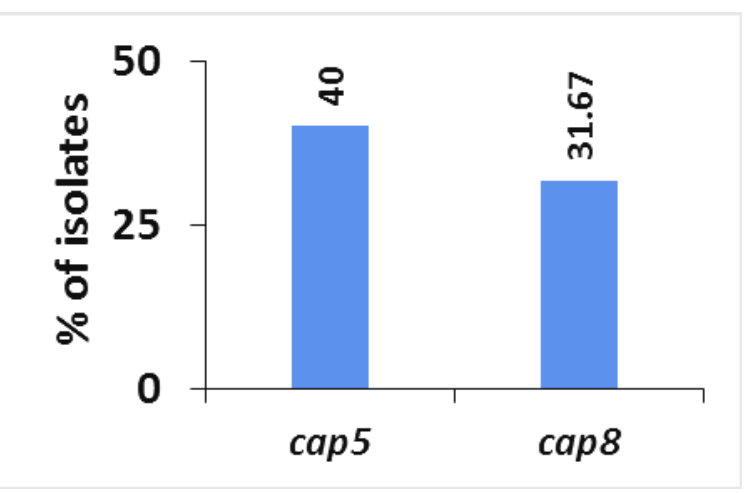

Figure 1. Prevalence of Capsular polysaccharides.

Another investigation was also carried out to find the prevalence of staphylococcal enterotoxin, toxic shock toxin, exfoliative toxins, hemolysin, adhesion and bone bound sialoprotein genes. Staphylococcal toxin is responsible for food poisoning and they disrupt water and electrolyte balance in the small intestine (Sheahan et al., 1970; Sullivan, 1969). Results revealed that (Figure 2) $26.67 \%(\mathrm{n}=16)$ of the isolates were positive for sea, $20 \%(\mathrm{n}=12)$ of the isolates were positive for seq, $6.67 \%(\mathrm{n}=4)$ of the isolates were positive for both seb and sec. Only the isolate Staphylococcus aureus M1 was seen to harbour the sed gene $(1.67 \%)$ and none was positive for see. Isolates harbouring the staphylococcal enterotoxin (SE) gene indicated the toxigenic and pathogenicity of the isolates
(Push et al., 2016). Pinchuk et al. (2010) found that staphylococcal enterotoxins (SEA to SEE) were mainly responsible for staphylococcal food poisoning. Besides, Staphylococcus strains producing exfoliative toxin (ETs) or toxic shock syndrome toxin (TSST-1) has been shown to be an important clinical implication (Becker et al., 1998). Out of the 60 isolates analyzed, only 3 (Staphylococcus aureus strain Mu50, Staphylococcus aureus subsp. aureus Mu3, Staphylococcus aureus subsp. aureus N315) were positive for tst gene having the prevalence 5\%. Alfatemi et al. (2014) reported earlier that the frequency of the tst gene was $11.64 \%$ in Staphylococcus spp. which is close the analyzed value. Study regarding eta or etb genes revealed that none of the isolates had these genes indicating no association with staphylococcal peeling skin syndrome.

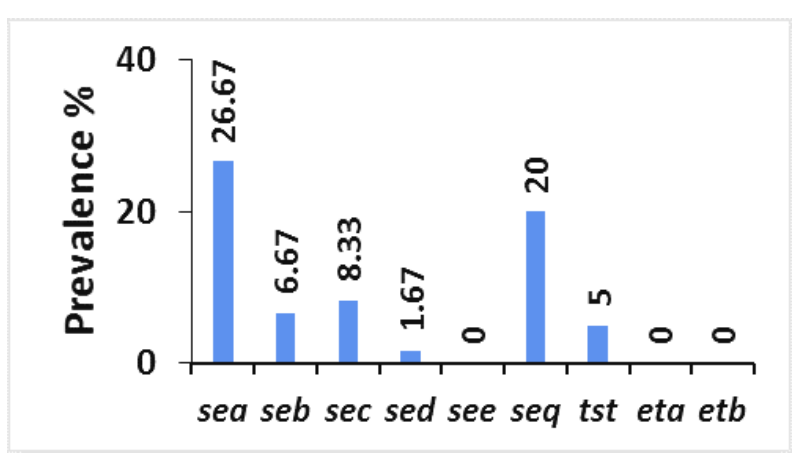

Figure 2. Prevalence of Staphylococcal toxin genes.

Hemolysin gene helps bacteria to invade host tissue (Lowy, 2000). The alpha, beta, delta and gamma hemolysin toxins are coded by hla, hlb, hld, and hlg genes, respectively. Among 60 isolates, 38 (63.33\%) harboured a $210 \mathrm{bp}$ amplicon for hla gene. Forty-five isolates (75\%) harboured 111 bp PCR amplicon for hld gene. Out of 60 isolates, 9 (15\%) were positive for the PCR amplicon of $310 \mathrm{bp}$ for hlb gene and $7(11.67 \%)$ were positive for the amplicon of 938 bp for hlg (Figure 3). Li et al. (2015) reported that food poisoning outbreaks in China were caused by hla and hld genes.

The icaA operon is essential for capsular polysaccharide synthesis and is a virulence marker of orthopedic infections (Arciola et al., 2003). The icaA gene is also required for biofilm formation (Cramton et al. 1999). Forty-eight isolates (80\%) carried the icaA gene and showed the PCR amplification 
product of $770 \mathrm{bp}$. The $b b p$ gene was responsible for hematogenous tissue infection (Tristan et al., 2003). It had PCR amplification product of $574 \mathrm{bp}$ and was available in only 3 isolates (Staphylococcus aureus subsp. aureus 55/2053, Staphylococcus aureus subsp. aureus MRSA252, Staphylococcus aureus subsp. aureus TCH60). The prevalence of $b b p$ gene was $5 \%$. The present study showed that icaA gene was detected at higher level than $b b p$ gene. This gene enhances the adherence of staphylococci to the host cells. These findings are in line with Park et al. (2008). The sdrE genes are associated with bone infections and present study found no sdrE positive isolates (Figure 4).

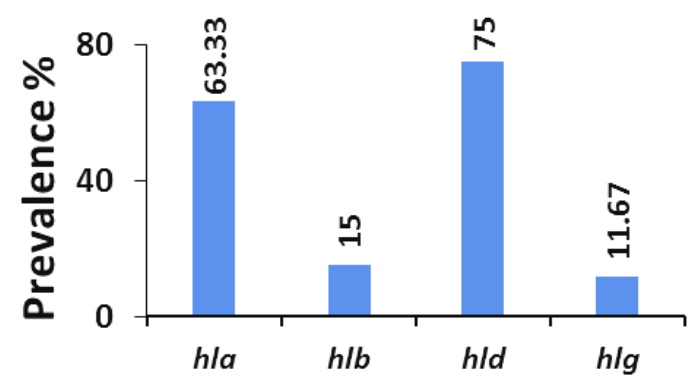

Figure 3. Prevalence of Hemolysin genes.

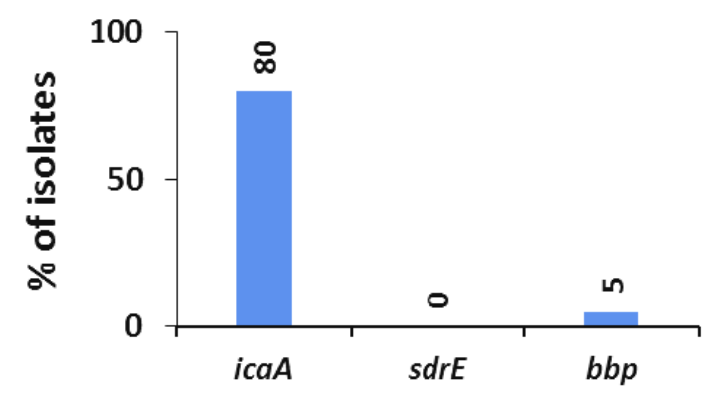

Figure 4. Prevalence of intracellular adhesin, putative adhesin and bone bound sialoprotein genes.

Antibiotic resistance makes Staphylococcus spp. to survive in the hostile environment and contribute to the outbreak of staphylococcal infections (Kumar et al., 2009). $\beta$-lactamase production in staphylococci is encoded by blaZ gene. Twenty-three samples (38.33\%) had the blaz gene. The incidence of penicillin resistance found in the present study shows similar trend with Adwan et al. (2014). Erythromycin resistance is developed by alteration of $23 \mathrm{~S}$ rRNA, which is a common binding site of macrolide, lincosamides and streptogramin B antibiotics. This modification is done by rRNA erm methylase (Sutcliffe et al., 1996). Twenty-three of the 60 samples had the ermA gene with the $139 \mathrm{bp}$ amplicon. None of the isolates were positive for ermB gene. Out of the 60 isolates analyzed, only 2 (Staphylococcus aureus subsp. aureus CN1 and Staphylococcus carnosus subsp. carnosus TM300) were positive for ermC. The $190 \mathrm{bp}$ gene product of ermC was present in $3.33 \%$ isolates. Nicola et al. (1998) and Westh et al. (1995) observed that erythromycin resistant $S$. aureus contained higher amount of ermA, no ermB and lower level of ermC. This is in agreement with the study of Martineau et al. (2000).

Lina et al. (1999) demonstrated that coagulasenegative staphylococci contained higher amount of msrA gene. Only isolates Staphylococcus aureus subsp. aureus 11819-97, Staphylococcus aureus subsp. aureus TW20 and Staphylococcus haemolyticus JCSC1435 harboured the msrA gene and one isolate (Staphylococcus haemolyticus JCSC1435) had the msrB gene. The mecA gene is responsible for resistance to methicillin and $\beta$-lactam antibiotics. It is usually expressed under antibiotic pressure. A total of 39 of the 60 samples had the mecA resistance gene with $174 \mathrm{bp}$ amplicon product. Prevalence of aac (6')-aph (2") gene was $15 \%$. The tet $M$ gene and tetK genes were found in $18.33 \%$ and $11.67 \%$ isolates, respectively (Figure 5).

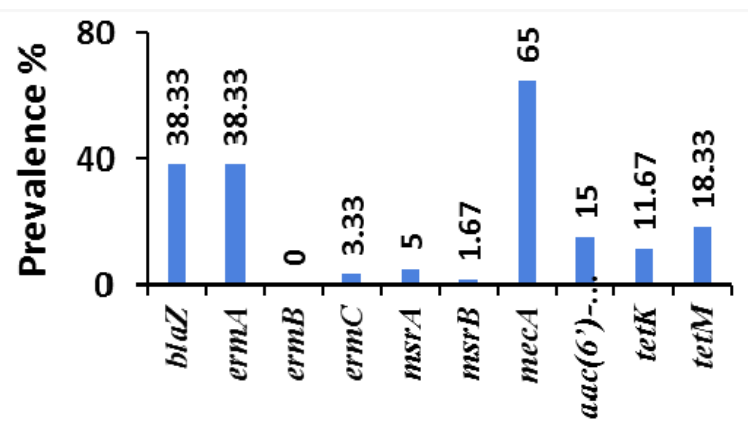

Figure 5. Prevalence of Antibiotic resistance genes.

The isolates were investigated by in silico pulsed field gel electrophoresis (PFGE), where fragments were obtained by SgrAI digestion. Dendrogram was 
constructed in the website. Isolates were able to be grouped into 23 genotypes at $50 \%$ similarity coefficient (Figure 7). Onasanya et al. (2003) reported two major groups of Staphylococcus aureus at 50\% similarity coefficient, while 12 different subgroups were obtained at $100 \%$ similarity coefficient. Genotype 7 was more prevalent (20\%) followed by genotype 8 and $9(10 \%)$ (Figure 6).

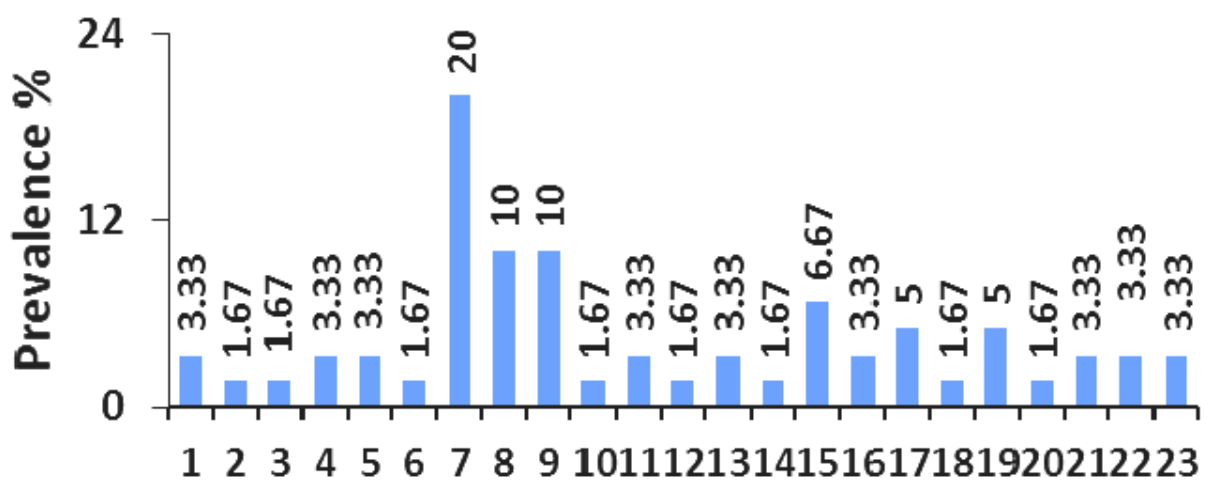

Figure 6. Prevalence of Genotypes.

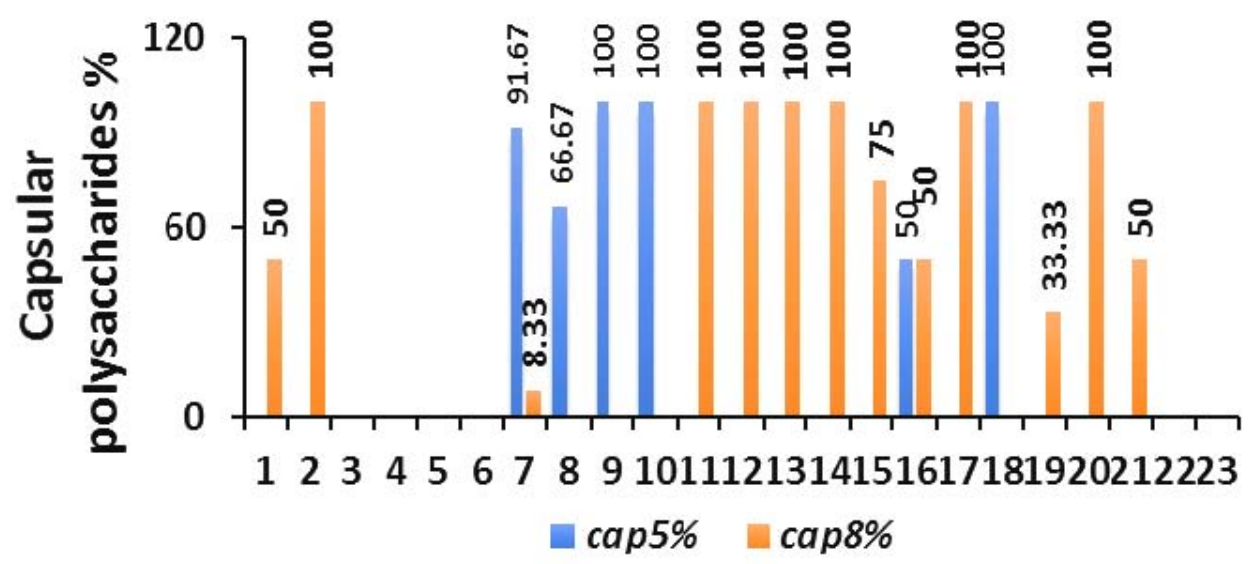

Figure 8. Distribution of cap5 and cap8 genes within genotypes.

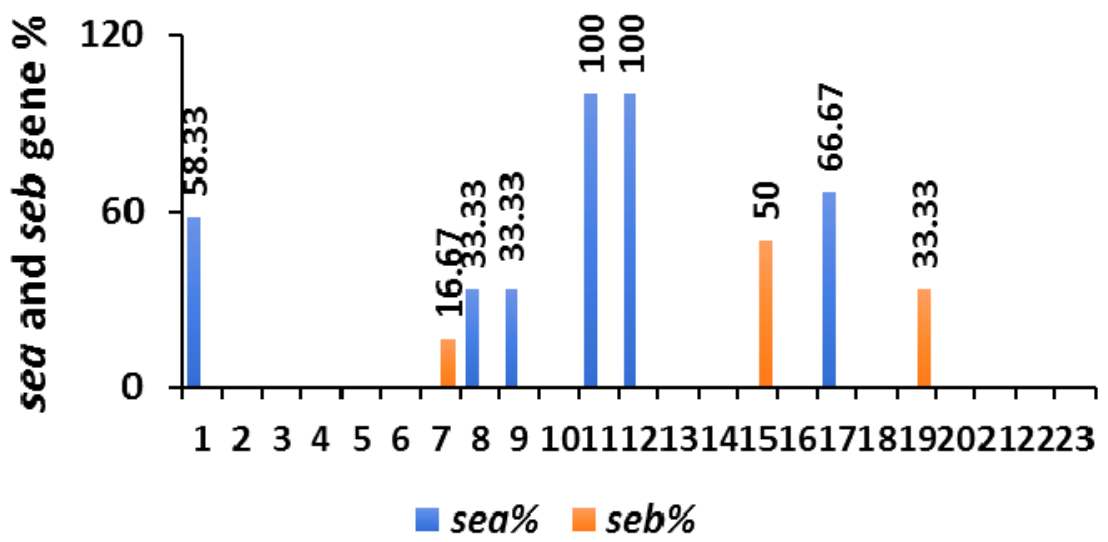

Figure 9. Distribution of sea and seb genes within genotypes. 


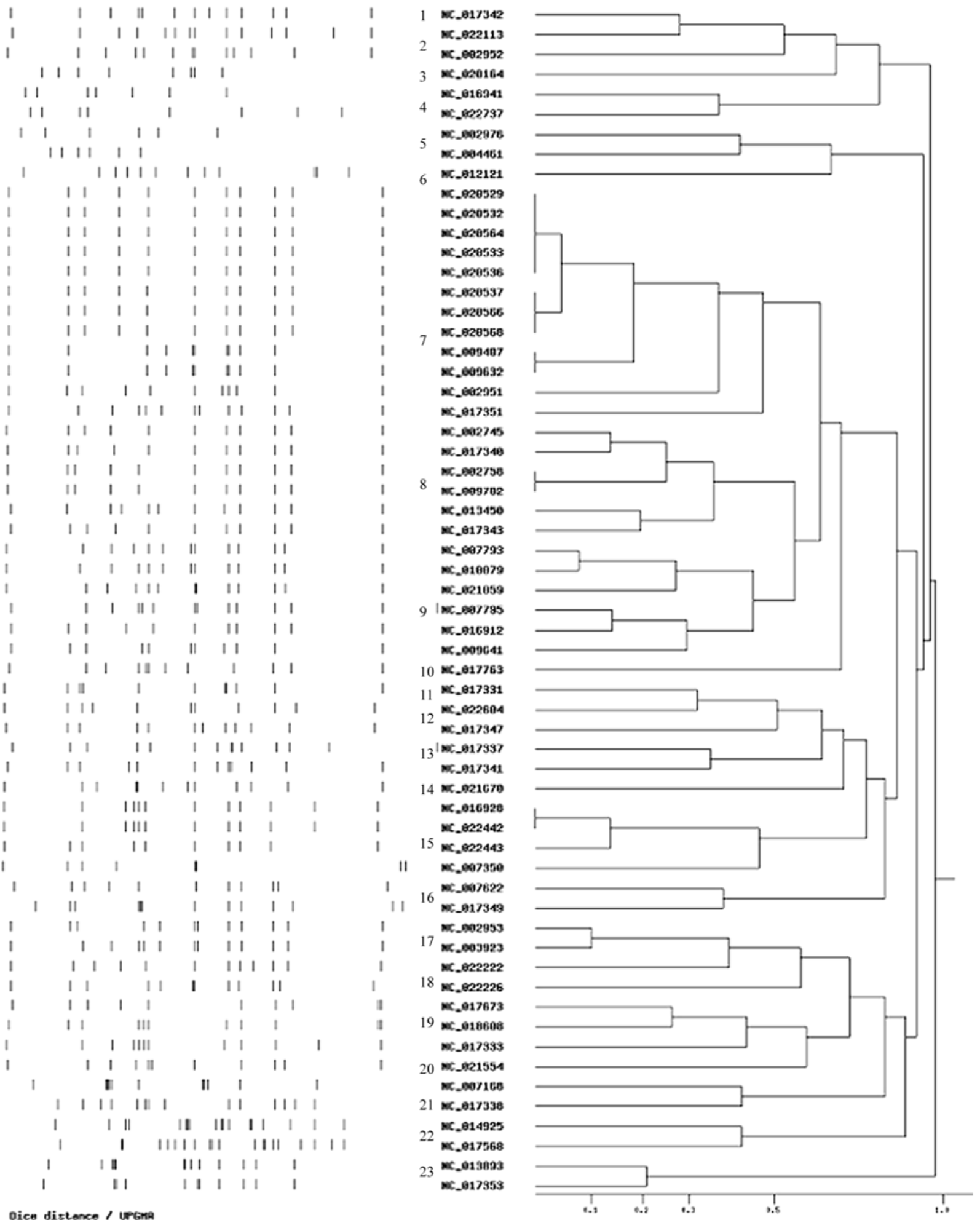

Figure 7. Phylogenetic diversity of Staphylococcus spp. identified by PFGE. 
Virulence genes mentioned in Table 2 had been analyzed in the present study. All genotypes were found to carry either cap5 or cap8 locus except genotype 3, 4, 5, 6, 22 and 23 (Figure 8). The cap5 locus was abundant in genotype 9,10 and $18(100 \%)$. On the other hand, the cap8 locus was prevalent in genotype 2, $11,12,13,14,17$ and 20 (100\%). Only genotype 16 and 7 carried both cap5 and cap8 locus. The presence of cap5 and cap 8 locus in different genotypes indicates the increased chances of pathogenicity. From the graphical presentation of sea and seb gene (Figure 9), it was found that sea gene was more prevalent than seb gene among the genotypes. Both of them were not present in same genotype. Genotype 11 and 12 carried the highest number sea gene (100\%). The seb gene was present in only genotype 7,15 and 19.

In addition, the sed gene was present only in genotype 9 displaying the prevalence 16.67\% (Figure 10 ). The availability of $\mathrm{sec}$ gene was $50 \%$ in genotype 8,16 and 17 and rest of the genotypes contained no sec or sed gene. In the same time, the tst positive isolates were present in genotype $8(50 \%)$ (Figure 11). The seq gene was more prevalent in genotype 11 and 12 followed by genotype 15,17, 13, 9 and 7. Both hla and $h l b$ genes were present in genotype 7, 9, 15, 16 and 17 (Figure 12). The hlb gene was abundant $(100 \%)$ in genotype 16. The hla genes were more prevalent in genotype $1,7,8,9,11,13,14,16$ and 18 (100\%).

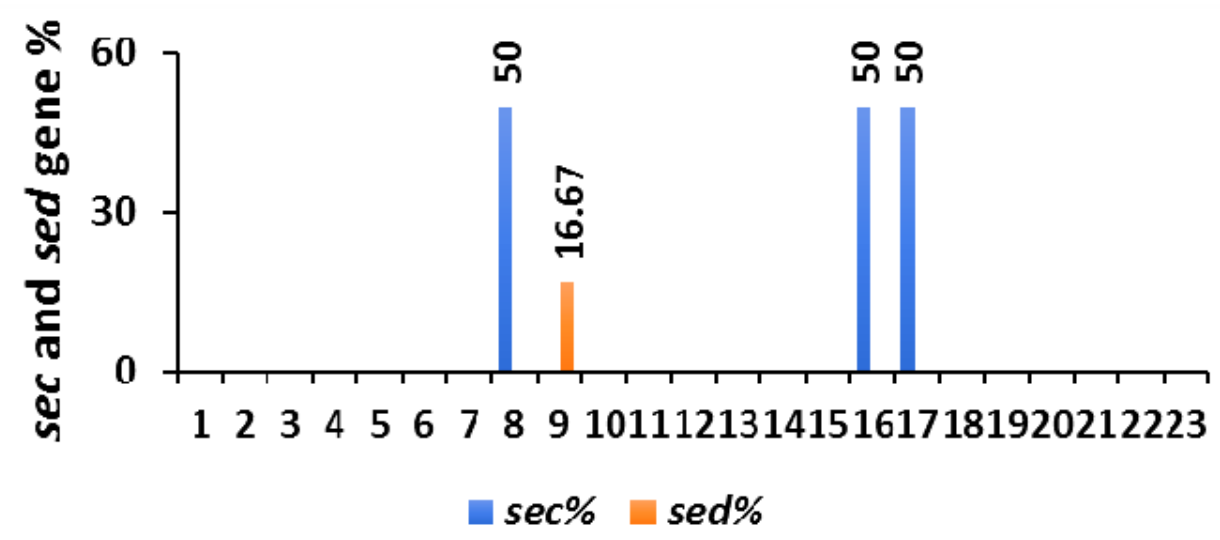

Figure 10. Distribution of sec and sed genes within genotypes.

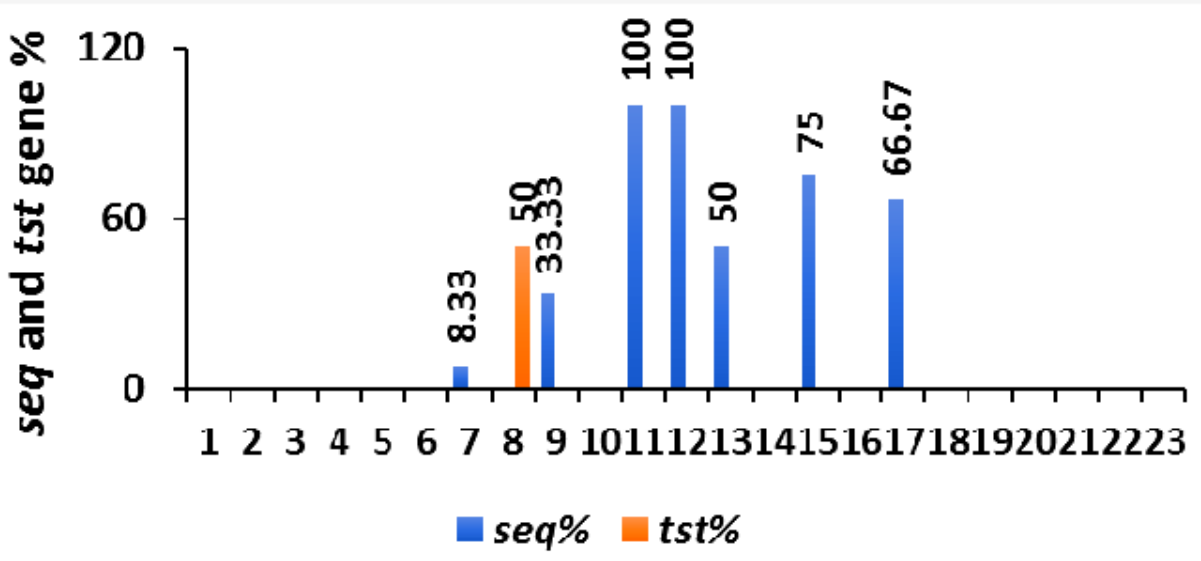

Figure 11. Distribution of seq and tst genes within genotypes. 


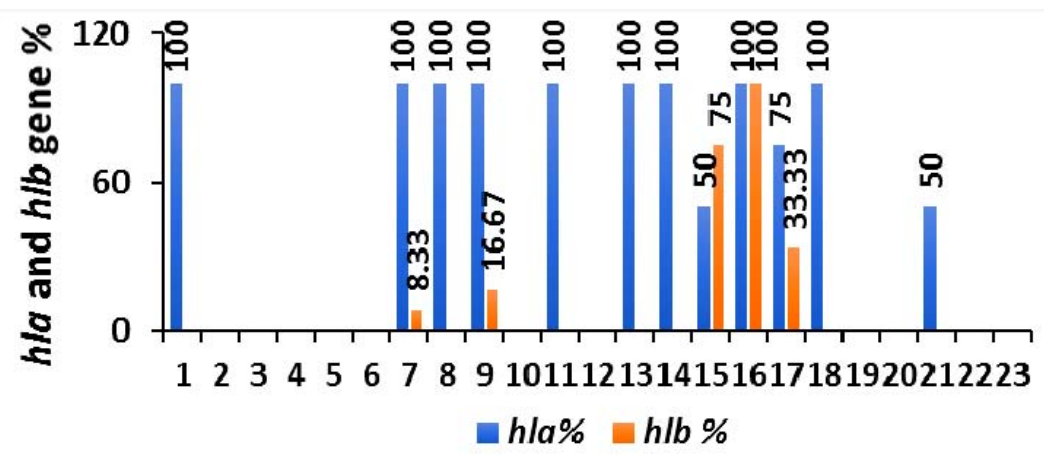

Figure 12. Distribution of hla and hlb genes within genotypes.

It was also observed that genotype 1, 2 and 19 carried both hld and hlg genes (Figure 13). Lower level of hld gene prevalence was encountered in genotype 13 and $21(50 \%)$. Seventy five percent isolates in genotype 15 harboured the hld gene. Besides, icaA gene was found more prevalent than $b b p$ gene among the genotypes (Figure 14). Only the genotype 1 and 2 carried both icaA and $b b p$ genes.

Study regarding the antibiotic resistance genes mentioned in Table 3 revealed that mecA gene was much more prevalent (Figure 15) and only absent in genotype 3, 6, 16, 22 and 23. The present study was also found that blaZ gene was present in $38.33 \%$ of the isolates. The blaZ gene was more abundant in genotype $1,2,3,11,12,14$ and $22(100 \%)$. Out of 23 genotypes, 10 genotypes harboured no blaZ gene (Figure 16). Besides, the ermA gene was prevalent in higher level in genotype 11, 12, 14 and 20 (100\%) (Figure 17). Genotype 5 contained both ermA and ermC genes and their prevalence within the genotypes was $50 \%$. In case of $m s r A$ and $m s r B$ genes (Figure 18), genotype 21 harboured both of these genes and their prevalence within the genotypes were $50 \%$. Other genotypes harboured no $m s r B$ gene.

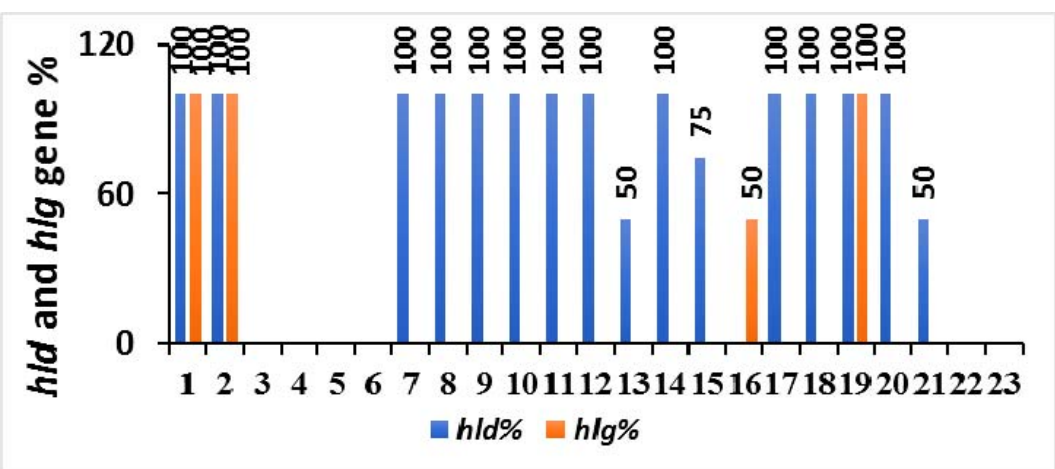

Figure 13. Distribution of $h l d$ and $h l g$ genes within genotypes.

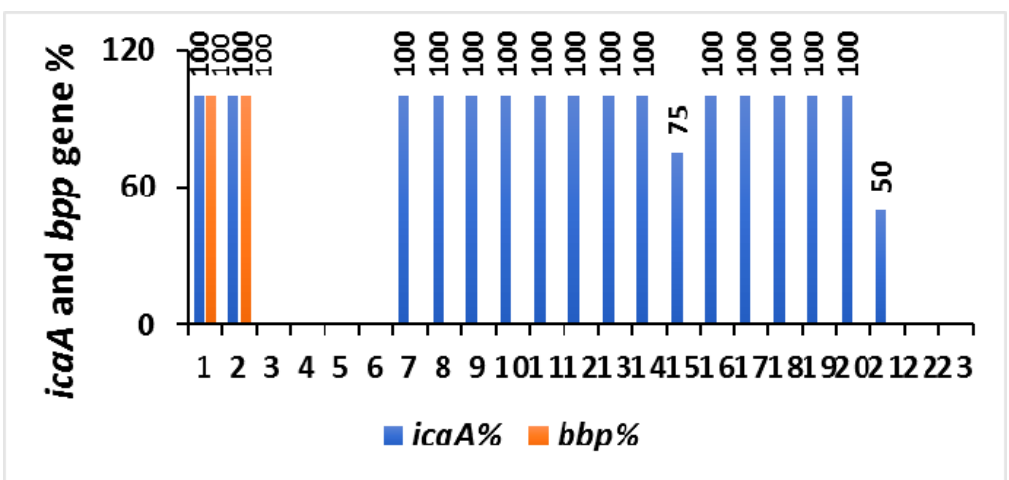

Figure 14. Distribution of icaA and bbp genes within genotypes. 


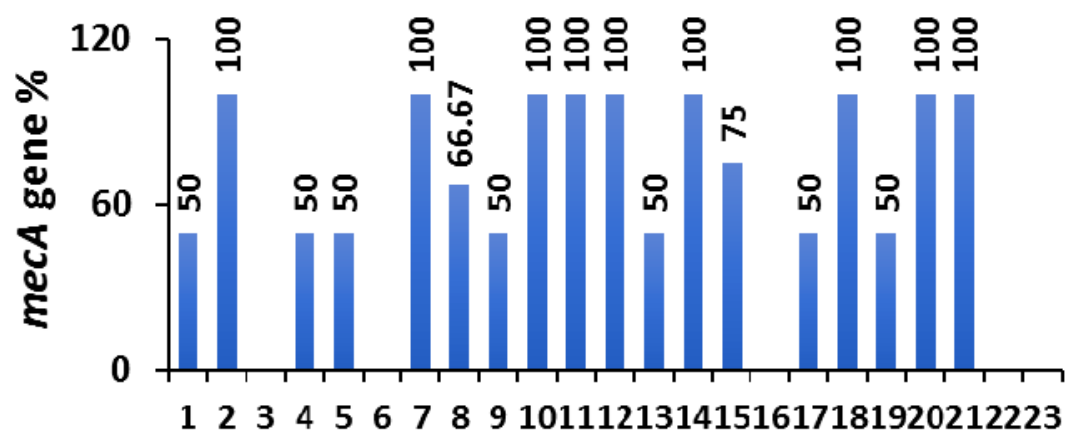

Figure 15. Distribution of mecA genes within genotypes.

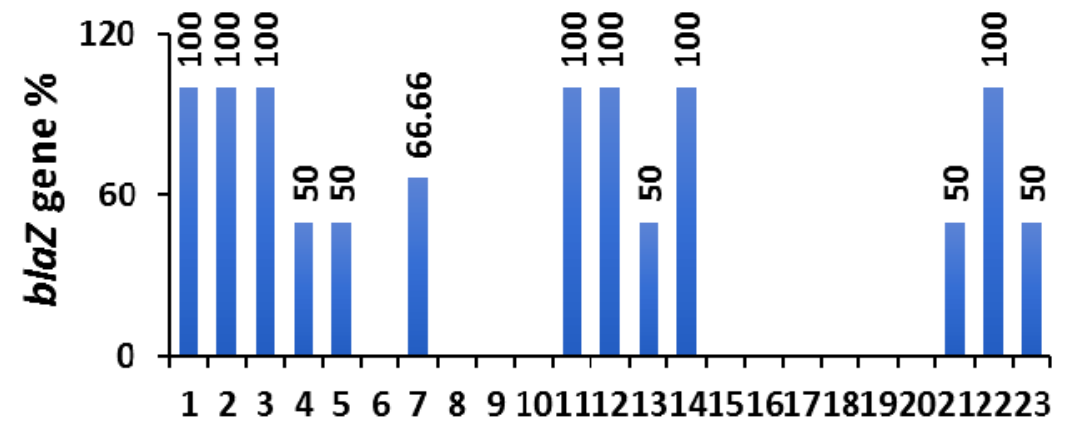

Figure 16. Distribution of blaZ genes within genotypes.

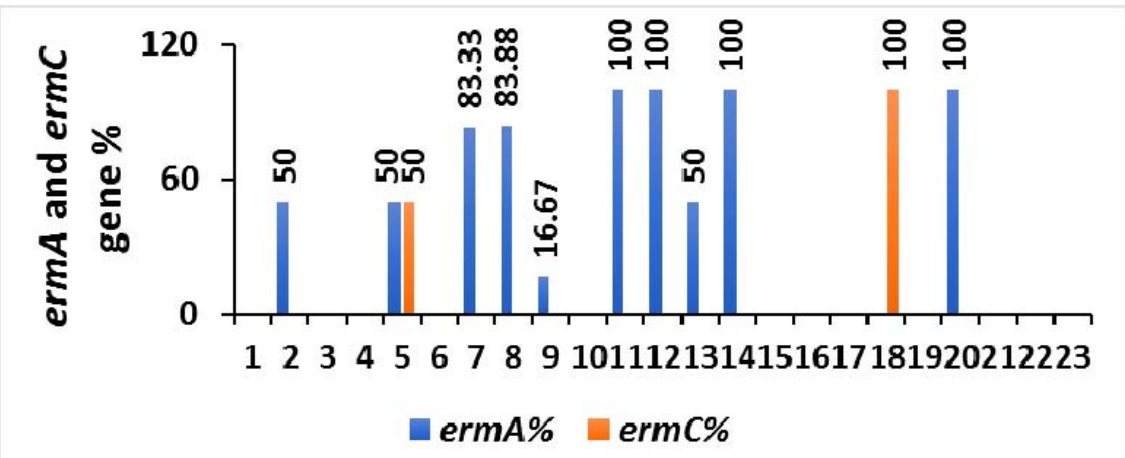

Figure 17. Distribution of ermA and ermC genes within genotypes.

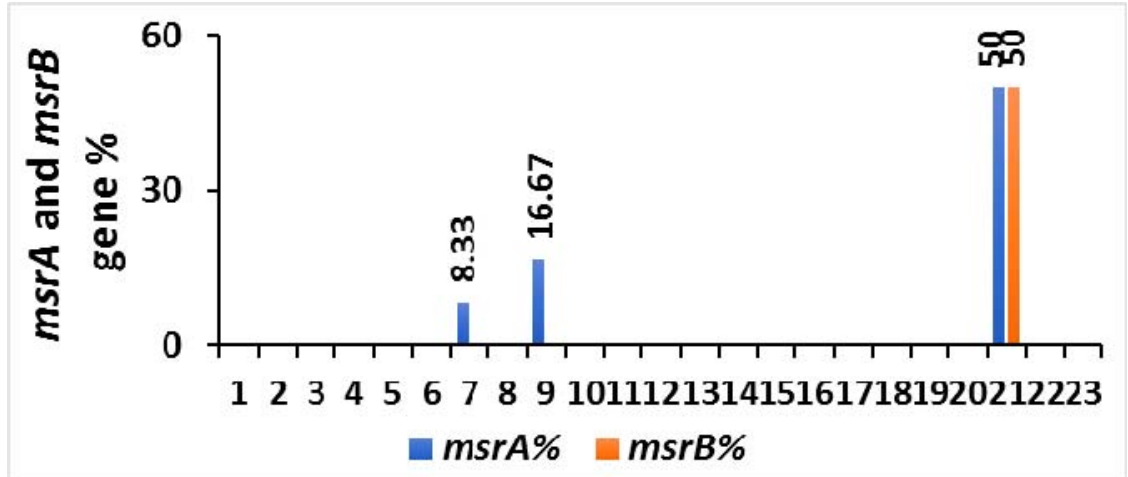

Figure 18. Distribution of $m s r A$ and $m s r B$ genes within genotypes. 


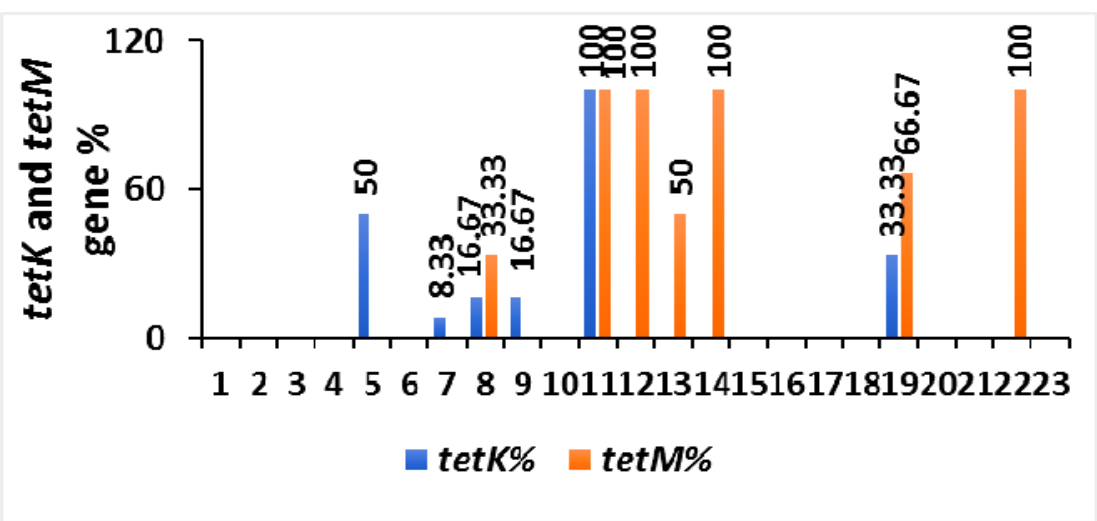

Figure 19. Distribution of tetK and tet $M$ genes within genotypes.

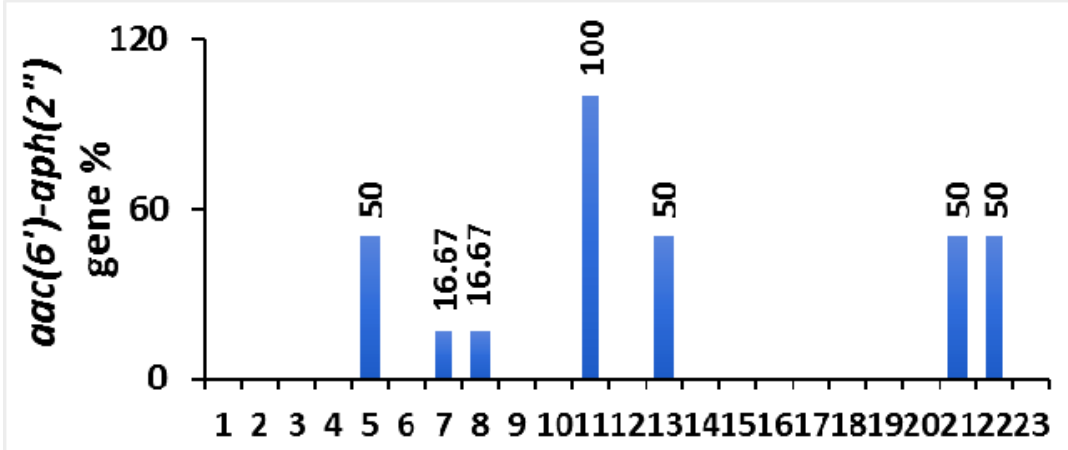

Figure 20. Distribution of aac (6')-aph (2”) genes within genotypes.

Figure 19 presents the distribution of tetK and tetM genes within genotypes. Genotype 8, 11 and 19 harboured both tetM and tetK genes. Genotype 11 carried same number of tetM and tetK genes (100\%). The prevalence of tetM genes in genotype 12, 14 and 22 was $100 \%$. Besides, the distribution of aac (6')-aph (2") genes within genotypes (Figure 20) found that genotype 11 contained the highest number of this gene. The prevalence of aac(6')-aph (2") gene in genotype 5, 13,21 and 22 was $50 \%$.

\section{Conclusion}

The icaA gene, accountable for intracellular adherence, was detected in $80 \%$ of the isolates. Hemolysin gene ( $h l a$ ) was also found in $63.33 \%$ of the isolates. The cap5 locus was detected in $40 \%$ of the isolates. Sixty five percent isolates harboured the mecA resistance gene. Both blaZ and ermA gene were detected in $38.88 \%$ of the isolates. No virulence genes were detected in genotype 3, 4, 5, 6, 22 and 23 . Genotype 1 was considered more virulent followed by genotype 11. Genotype 1 harboured six virulent genes and all hemolysin genes were present except $h l b$ gene. Genotype 11 harboured six antibiotic resistance genes except $m s r A, m s r B$, ermB and ermC. Genotype 6 and 16 carried no antibiotic resistance gene. Thus, this study has provided epidemiological data to study the characteristics of Staphylococcus strains and the virulence factors associated with infection.

\section{References}

Adwan, G.K., Naser, J. and Alaa, A. 2014. Molecular detection of nine antibiotic resistance genes in methicillin resistant Staphylococcus aureus isolates. Roum. Arch. Mircobio. Immunol. 73, 9-18.

Alfatemi, S.M.H., Motamedifar, M., Hadi, N. and Saraie, H.S.E. 2014. Analysis of virulence genes among methicillin resistant Staphylococcus aureus (MRSA) strains. Jundishapur J. Microb.7, e10741. 
Arciola, C.R., Campoccia, D., Gamberini, S., Donati, M.E., Baldassarri, L. and Montanaro, L. 2003. Occurrence of ica genes for slime synthesis in a collection of Staphylococcus epidermidis strains from orthopedic prosthesis infections. Acta. Orthop. Scand. 74, 617-621.

Argudin, M.A., Mendoza, M.C., Gonzalez-Hevia, M.A., Bances, M., Guerra, B. and Rodicio, M.R. 2012. Genotypes, exotoxin gene content, and antimicrobial resistance of Staphylococcus aureus strains recovered from foods and food handlers. Appl. Environ. Microbiol. 78, 2930-2935.

Becker, K., Pagnier, I., Schuhen, B., Wenzelburger, F., Friedrich, A.W., Kipp, F., Peters, Begier, E.M., Frenette, K. and Barrett, N.L. 2004. A high-morbidity outbreak of methicillin-resistant Staphylococcus aureus among players on a college football team, facilitated by cosmetic body shaving and turf burns. Clin. Infect. Dis. 39, 1446-1453.

Bikandi, J., San Millán, R., Rementeria, A. and Garaizar, J. 2004. In silico analysis of complete bacterial genomes: PCR, AFLP-PCR and endonuclease restriction. Bioinformatics 20, 798-799.

Biswas, S., Didier Raoult, D. and Rolain, J. 2008. A bioinformatic approach to understanding antibiotic resistance in intracellular bacteria through whole genome analysis. Int. J. Antimicrob. Agents. 32, 207-220.

Cramton, S.E., Gerke, C., Schnell, N.F., Nichols, W.W and Götz, F. 1999. The intercellular adhesion (ica) locus is present in Staphylococcus aureus and is required for biofilm formation. Infect. Immun. 67, 5427-5433.

Duran, N., Ozer, B., Duran, G.G., Onlen, Y. and Demir, C. 2012. Antibiotic resistance genes and susceptibility patterns in staphylococci. Indian J. Med. Res. 135, 389.

Feng, Y., Chen, C.J., Su, L.H., Hu, S., Yu, J. and Chiu, C.H. 2008. Evolution and pathogenesis of Staphylococcus aureus: lessons learned from genotyping and comparative genomics. FEMS. Microbiol. Rev. 32, 2337.

Fueyo, J.M., Mendoza, M.C. and Martin, M.C. 2005. Enterotoxins and toxic shock syndrome toxin in Staphylococcus aureus recovered from human nasal carriers and manually handled foods: Epidemiological and genetic findings. Microb. Infect. 7, 187-194.

Hennekinne, J.A., de Buyser, M.L. and Dragacci, S. 2012. Staphylococcus aureus and its food poisoning toxins: Characterization and outbreak investigation. FEMS. Microbiol. Rev. 36, 815-836.

Hochkeppel, H.K., Braun, D.G., Vischer, W., Imm, A., Sutter, S., Staeubli, U., Guggenheim, R., Kaplan, E.L., Boutonnier, A. and Fournier, J.M. 1987. Serotyping and electron microscopy studies of Staphylococcus aureus clinical isolates with monoclonal antibodies to capsular polysaccharide types 5 and 8 . J. Clin. Microbiol. 25, 526-530.
Jarraud, S., Mougel, C., Thioulouse, J., Lina, G., Meugnier, H., Forey, F., Nesme, X., Etienne, J. and Vandenesch, F. 2002. Relationships between Staphylococcus aureus genetic background, virulence factors, agr groups (alleles), and human disease. Infect. Immun. 70, 631-641.

Kim, J.S., Song, W., Kim, H.S., Cho, H.C., Lee, K.M., Choi, M.S. and Kim, E.C. 2006. Association between the methicillin resistance of clinical isolates of Staphylococcus aureus, their staphylococcal cassette chromosome mec (SCCmec) subtype classification, and their toxin gene profiles. Diagn. Microbiol. Infect. Dis. 56, 289-295.

Kumar, J.D., Negi, Y.K., Gaur, A. and Khanna, D. 2009. Detection of virulence genes in Staphylococcus aureus isolated from paper currency. Int. J. Inf. Dis. 13, 450455.

Li, G., Wu, S., Luo, W., Su, Y., Luan, Y. and Wang, X. 2015. Staphylococcus aureus ST6-t701 isolates from foodpoisoning outbreaks (2006-2013) in Xi'an, China. Foodborne Pathog. Dis. 12, 203-206.

Lina, G., Quaglia, A., Reverdy, M.E., Leclercq, R., Vandenesch, F. and Etienne, J. 1999. Distribution of genes encoding resistance to macrolides, lincosamides, and streptogramins among staphylococci. Antimicrob. Agents Chemother. 43, 1062-1066.

Lowy, F.D. 2000. Is Staphylococcus aureus an intracellular pathogen? Trends Microbiol. 8, 341-343.

Luong, T., Sau, S., Gomez, M., Lee, J.C. and Lee, C.Y. 2002. Regulation of Staphylococcus aureus capsular polysaccharide expression by agr and sarA. Infect. Immun. 70, 444-450.

Martineau, F., Picard, F. J., Grenier, L., Roy, P.H., Ouellette, M. and Bergeron, M.G. 2000. Multiplex PCR assays for the detection of clinically relevant antibiotic resistance genes in staphylococci isolated from patients infected after cardiac surgery. J. Antimicrob. Chemother. 46, 527534.

Momtaz, H., Dehkordi, F.S., Rahimi, E., Asgarifar, A. and Momeni, M. 2013. Virulence genes and antimicrobial resistance profiles of Staphylococcus aureus isolated from chicken meat in Isfahan province, Iran. J. Appl. Poultry Res. 22, 913-921.

Na'Was, T., Hawwari, A., Hendrix, E., Hebden, J., Edelman, R., Martin, M., Campbell, W., Naso, R., Schwalbe, R. and Fattom, A.I. 1998. Phenotypic and genotypic characterization of nosocomial Staphylococcus aureus isolates from trauma patients. J. Clin. Microbiol. 36, 414-420.

Nicola, F.G., McDougal, L.K., Biddle, J.W. and Tenover, F.C. 1998. Characterization of erythromycin-resistant isolates of Staphylococcus aureus recovered in the United States from 1958 through 1969. Antimicrob. Agents Chemother. 42, 3024-7. 
Onasanya, A., Mignouna, H.D. and Thottappilly, G. 2003. Genetic fingerprinting and phylogenetic diversity of Staphylococcus aureus isolates from Nigeria. Afr. J. Biotechnol. 2, 246-250.

O'Riordan, K. and Lee, J.C. 2004. Staphylococcus aureus capsular polysaccharides. Clin. Microbiol. Rev. 17, 218234.

Park, H.K., Woo, S.Y., Jung, Y.J., Lee, E.O., Cha, J.E., Park, H.S. and Lee, S.J. 2008. Detection of virulence genes of Staphylococcus aureus and Staphylococcus epidermidis isolated from suprapubic urine from infants with fever. $J$. Bacteriol. Virol. 38, 189-196.

Peacock, S.J., Moore, C.E., Justice, A., Kantzanou, M., Story, L. and MacKie, K., et al. 2002. Virulent combinations of adhesion and toxin genes in natural populations of Staphylococcus aureus. Infect. Immun. 70, 4987-4996.

Pinchuk, I.V., Beswick, E.J. and Reyes, V.E. 2010. Staphylococcal enterotoxins. Toxins (Basel). 2, 21772197.

Puah, S.M., Chua, K.H. and Tan, J.A.M.A. 2016. Virulence factors and antibiotic susceptibility of Staphylococcus aureus isolates in ready-to-eat foods: detection of $S$. aureus contamination and a high prevalence of virulence genes. Int. J. Environ. Res. Public Health. 13, 199.

Saadati, M., Barati, B., Doroudian, M., Shirzad, H., Hashemi, M., Hosseini, S.M. and Imani, S. 2011. Detection of sea, seb, sec, seq genes in Staphylococcus aureus isolated from nasal carriers in Tehran province, Iran; by multiplex PCR. J. Param. Sci. 2, ISSN 2008-4978.

Salasia, S.I.O., Khusnan, Z., Lammler, C. and Zschock, M. 2004. Comparative studies on pheno-and genotypic properties of Staphylococcus aureus isolated from bovine subclinical mastitis in central Java in Indonesia and Hesse in Germany. J. Vet. Sci. 5, 103-109.

San Millán, R.M., Martínez-Ballesteros, I., Rementeria, A., Garaizar, J. and Bikandi, J. 2013. Online exercise for the design and simulation of PCR and PCR-RFLP experiments. BMC. Res. Notes 6, 513.

Schmitz, F.J., Krey, A., Sadurski, R., Verhoef, J., Milatovic, D. and Fluit, A.C. 2001. Resistance to tetracycline and distribution of tetracycline resistance genes in European Staphylococcus aureus isolates. J. Antimicrob. Chemother. 47, 239-240.

Schmitz, F.J., Petridou, J., Fluit, A.C., Hadding, U., Peters, G., Von Eiff, C. and MARS study Group. 2000. Distribution of macrolide-resistance genes in Staphylococcus aureus blood-culture isolates from fifteen German university hospitals. Eur. J. Clin. Microbiol. Infect. Dis. 19, 385-387.
Sheahan, D.G., Jervis, H.R., Takeuchi, A. and Sprinz, H. 1970. The effect of staphylococcal enterotoxin on the epithelial mucosubstances of the small intestine of rhesus monkeys. Am. J. Pathol. 60, 1.

Sullivan Sr, R.S. 1969. Effects of enterotoxin B on intestinal transport in vitro. Proc. Soc. Exp. Biol. Med. 131, 11591162.

Sutcliffe, J., Grebe, T., Tait-Kamradt, A. and Wondrack, L. 1996. Detection of erythromycin-resistant determinants by PCR. Antimicrob. Agents Chemother. 40, 2562-2566.

Torres, G. M., Tejedor Junco, M.T., Gonzalez, M.M. and Gonzalez, L.Z. 1996. Selection of subpopulations resistant to amikacin and netilmicin of gentamicinresistant clinical strains of Staphylococcus aureus and Staphylococcus epidermidis. Zentbl. Bakteriol. 284, 5866.

Tristan, A., Ying, L., Bes, M., Etienne, J., Vandenesch, F. and Lina. G. 2003. Use of multiplex PCR to identify Staphylococcus aureus adhesins involved in human hematogenous infections. J. Clin. Microbiol. 41, 4465-4467.

Trzcinski, K., Cooper, B.C., Hryniewicz, W. and Dowson, C.G. 2000. Expression of resistance to tetracyclines in strains of methicillin-resistant Staphylococcus aureus. J. Antimicrob. Chemother. 45, 763-770.

Vandenesch, F., Lina, G. and Henry, T. 2012. Staphylococcus aureus hemolysins, bi-component leukocidins, and cytolytic peptides: A redundant arsenal of membranedamaging virulence factors? Front. Cell Infect. Microbiol. 2, 12.

Westh, H., Hougaard, D.M., Vuust, J. and Rosdahl, V.T. 1995. Prevalence of erm gene classes in erythromycinresistant Staphylococcus aureus strains isolated between 1959 and 1988. Antimicrob. Agents Chemother. 39, 36973.

Zankari, E., Hasman, H., Cosentino, S., Vestergaard, M., Rasmussen, S., Lund, O., Aarestrup, F.M. and Larsen, M. 2012. Identification of acquired antimicrobial resistance genes. J. Antimicrob. Chemother. 67, 26402644. 